\title{
On the synonymy of two Acantholycosa species (Araneae, Lycosidae) from the Altai
}

\author{
Alexander A. Fomichev', Yuri M. Marusik ${ }^{2,3,4}$, Seppo Koponen ${ }^{5}$ \\ I Altai State University, Lenina Pr., 61, Barnaul, RF-656049, Russia 2 Institute for Biological Problems of the \\ North RAS, Portovaya Str. 18, Magadan 685000, Russia 3 Department of Zoology \& Entomology, University \\ of the Free State, Bloemfontein 9300, South Africa 4 Far Eastern Federal University, Sukhanova 8, Vladivostok \\ 690950, Russia 5 Zoological Museum, University of Turku, FI-20014 Turku, Finland
}

Corresponding author: Alexander A. Fomichev (a.fomichov@mail.ru)

Academic editor: Cor Vink | Received 2 November 2015 | Accepted 11 January 2016 | Published 3 February 2016

http://zoobank.org/D28F9COB-E43C-4601-82D8-EB8AC259C734

Citation: Fomichev AA, Marusik YM, Koponen S (2016) On the synonymy of two Acantholycosa species (Araneae, Lycosidae) from the Altai. ZooKeys 559: 151-156. doi: 10.3897/zookeys.559.7048

\begin{abstract}
Two species previously known from East Kazakhstan, Acantholycosa katunensis Marusik, Azarkina \& Koponen, 2004, known from the holotype male, and A. kurchumensis Marusik, Azarkina \& Koponen, 2004, syn. n. known from females, are synonymized, and priority is given to A. katunensis. Acantholycosa katunensis is reported for the first time in the Russian Altai. Both sexes of this species are illustrated, and a distribution map is provided.
\end{abstract}

\section{Keywords}

Aranei, wolf spider, South Siberia, Russia, new record, new synonymy 


\section{Introduction}

Acantholycosa Dahl, 1908 is one of the best studied among species-rich Pardosinae genera in the Holarctic due to a revision (Marusik et al. 2004), a regional review (Marusik and Omelko 2011) and several species surveys (Kronestedt and Marusik 2002; Fomichev and Marusik 2011; Marusik and Logunov 2011). Nevertheless, its taxonomy has remained improperly studied. Over one third of Acantholycosa species are known from only a single sex (two from females and eight from males). All these species are either endemic to the Altai-Sayan Mountain region (nine species) or the Sikhote-Alin' Mountain Range (one species). Such a high number of species known only from one sex may be because of the habitat preference of Acantholycosa species. With one exception (A. lignaria (Clerck, 1757)), all species inhabit stony screes in mountains, and this habitat is difficult to reach and study. So far, 29 species are known in the genus (World Spider Catalog 2015), most of which (20) occur in the Altai-Sayan Mountain region (Marusik et al. 2004).

While studying material from the Russian Altai, the first author found two species from nearby localities, A. katunensis Marusik, Azarkina \& Koponen, 2004 and $A$. kurchumensis Marusik, Azarkina \& Koponen, 2004, both previously known from East Kazakhstan. The former species, assigned to the azyuzini-group, was known from the holotype male from Rakhmanovskiye Klyuchi Village, and the latter species, assigned to the dudkorum-species group, was known from three females from two localities, the Kurchum River and Rakhmanovskiye Klyuchi. Marusik et al. (2004) suggested that these two species found in a single locality (Rakhmanovskiye Klyuchi) could be conspecific. The occurrence of these two species A. katunensis and A. kurchumensis in another locality led us to the conclusion that they are conspecific, and the tentative placement of these species into different species groups by Marusik et al. (2004) was incorrect. Additional arguments in support of the conspecificity of two species are the same spination of tibia I (5-6 proventral and 4-5 retroventral spines) and also that these species in South-Western Altai are the only known species by opposite sexes. The goal of this paper is to synonymize the two species, provide an illustrated redescription of both sexes and new data about species distribution.

\section{Material and methods}

Specimens were photographed with a Canon EOS 7D camera attached to an Olympus SZX16 stereomicroscope at the Zoological Museum, University of Turku, Finland. Digital images were montaged using "CombineZP" image stacking software. Epigynes were cleared in a $\mathrm{KOH} /$ water solution until soft tissues were dissolved. Photographs were taken in dishes with paraffin on the bottom to hold the specimens in position. Background maps are from Microsoft Encarta Premium 2009. All material examined is deposited in the Institute for Systematic and Ecology of Animals, Novosibirsk (ISEA). 


\section{Taxonomy}

\section{Acantholycosa katunensis Marusik, Azarkina \& Koponen, 2004}

Figs $1-10$

A. katunensis Marusik, Azarkina \& Koponen, 2004: 107, figs 21-23 (ふ).

A. kurchumensis Marusik, Azarkina \& Koponen, 2004: 119, figs 82-83 (†). Syn. n.

Material examined. RUSSIA, Altai Republic, Kosh-Agach District: $3{ }^{\lambda}$ (ISEA), Karagemskyi Mt. Range (49 $52^{\circ} \mathrm{N}$; 8707'E), 2500-2900 m, "kurums" (=scree formed by huge boulders) and alpine meadow, 27.06.2014 (A.A. Fomichev); 1 ㅇ (ISEA), Karagem River valley $\left(49^{\circ} 53^{\prime} \mathrm{N}\right.$; $\left.87^{\circ} 11^{\prime} \mathrm{E}\right), 1360 \mathrm{~m}$, stony steppe slope, 28.06.2014 (A.A. Fomichev); KAZAKHSTAN, East Kazakhstan Area: $10^{\lambda}$ (holotype of A. katunensis) (ISEA) South Altai, south part of Katun' Mt. Range, $5 \mathrm{~km}$ SE of Rakhmanovskiye Klyuchi (=Springs), 2100-2500 m, alpine zone, 26.06.1997 (R.Yu. Dudko and V.K. Zinchenko); 1 ㅇ (holotype of A. kurchumensis) (ISEA) Kurchum Mt. Range, Kurchum River, upper flow, 23.08.1990 (V.K. Zinchenko).

Diagnosis. Acantholycosa katunensis is most similar to A. dudkorum Marusik, Azarkina \& Koponen, 2004 by having a similarly shaped tegular apophysis that lacks an apical arm, a similar conductor, a wide apical pocket and a thin septum. The two species can be separated by the shape of the embolus, which tapers toward the tip in $A$. katunensis (Figs 3-5) and widens in A. dudkorum (cf. Marusik et al. 2004: figs 73, 75); the shape of

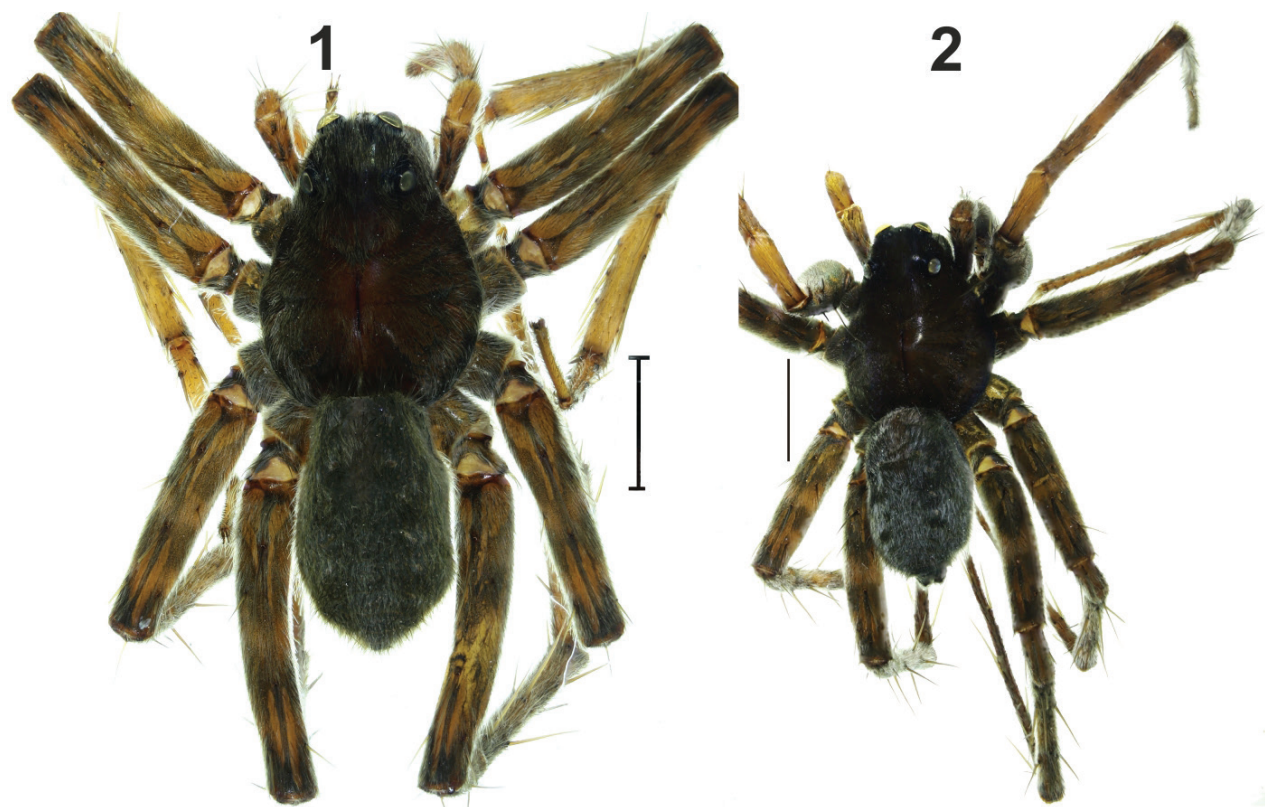

Figures I-2. Habitus of Acantholycosa katunensis. I female $\mathbf{2}$ male. Scale: 2 mm. 


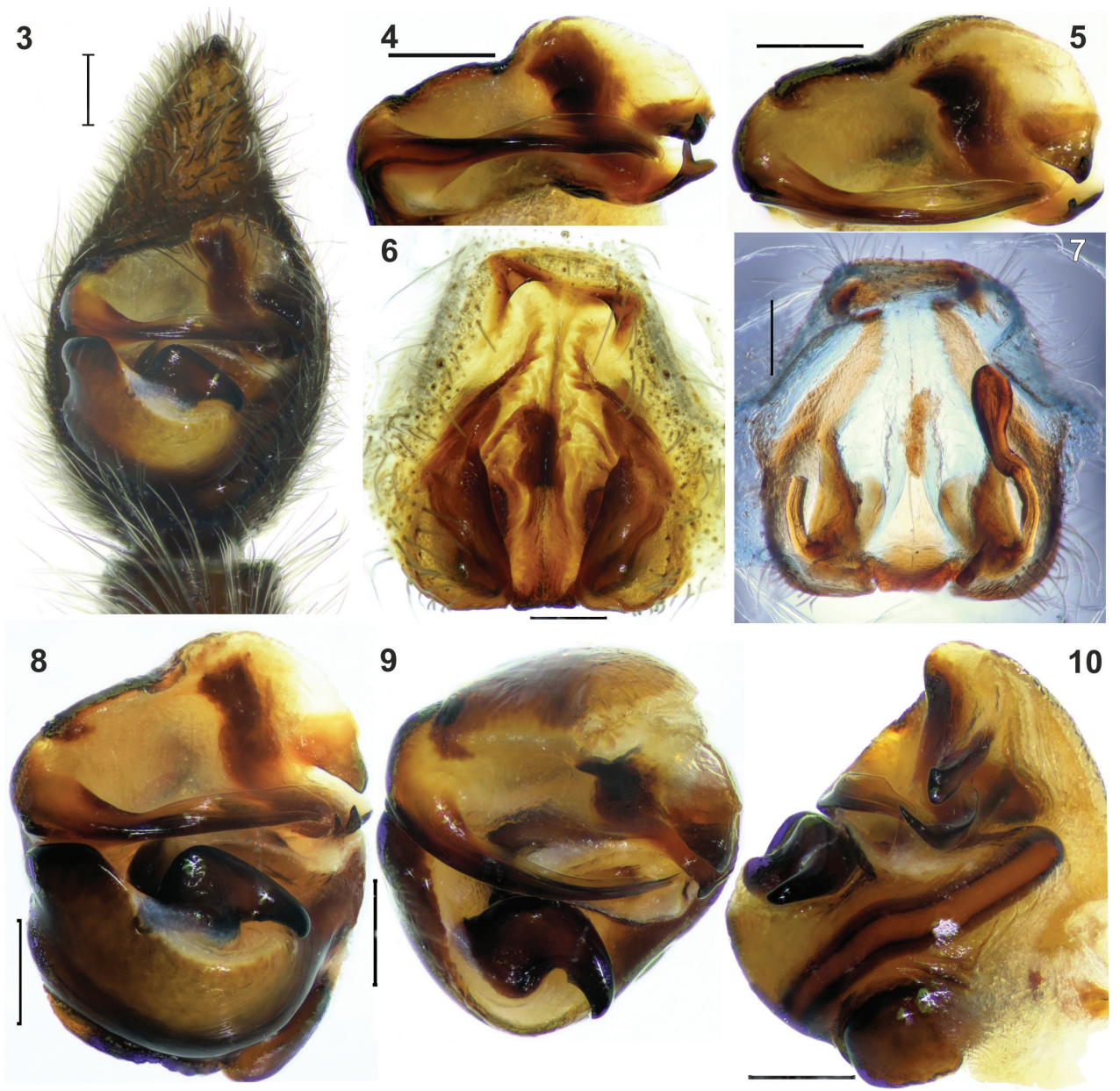

Figures 3-10. Copulatory organs of Acantholycosa katunensis. 3 male palp, ventral 4-5 embolic division, ventral and anterior 6-7 epigyne, ventral and dorsal (left head of receptacle is broken) 8-10 bulb, ventral, anterior and retrolateral. Scale: $0.2 \mathrm{~mm}$.

the palea: in $A$. dudkorum (cf. Marusik et al. 2004: figs 73, 75), the paleal process is thin with a hollow on the prolateral side, and it is unmodified in A. katunensis (Figs 4-5, 9). Females of the two species can be distinguished by the shape of septum: long (starting from the pocket) with a subparallel base in $A$. katunensis and short (starting from fovea) and widened at the base in $A$. dudkorum (cf. Marusik et al. 2004: fig. 78).

Description. See Marusik et al. (2004).

Distribution. So far, this species is known from three localities. The most distant localities, the upper reaches of the Kurchum River (locality 1, Map 1) and the Karagemskyi Mt Range (locality 3) are approximately 190 km apart (Map 1). Rakhmanovskiye Klyuchi Village (locality 2), the type locality of $A$. katunensis, is located between two extreme distribution records (Map 1). Listings for the species by Platnick 


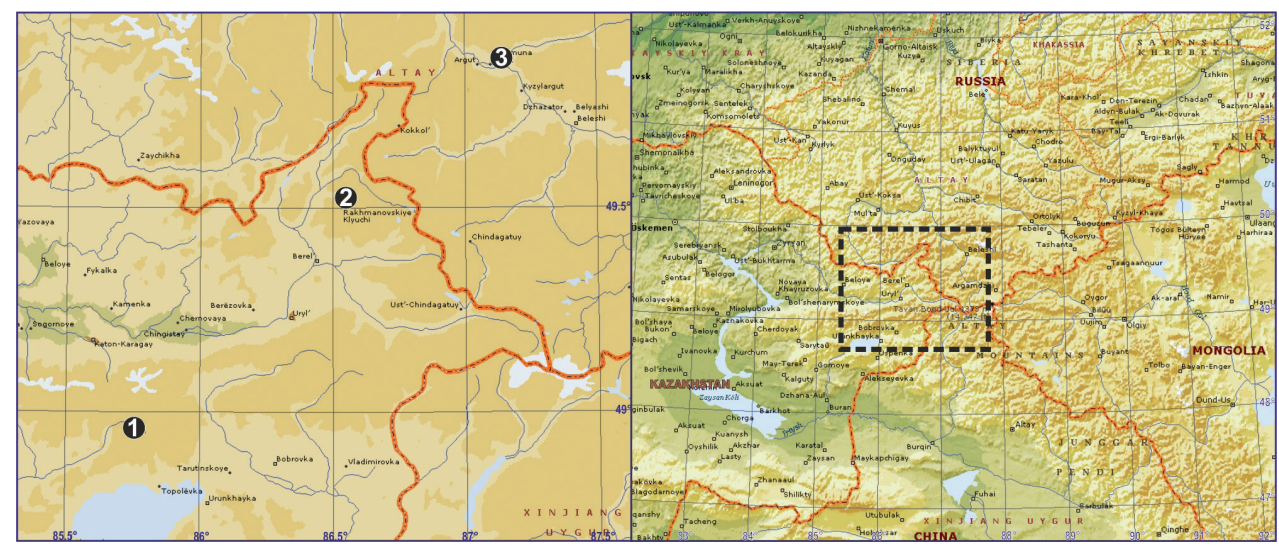

Map I. Distribution records of Acantholycosa katunensis. I Kurchum River 2 Rakhmanovskiye Klyuchi Village 3 Karagemskyi Mt. Range.

(2004-2014) and the World Spider Catalog (2015) for Russia were erroneous based on wrong country data provided by Marusik et al. (2004). Type locality of $A$. $k a-$ tunensis was mistakenly assigned to Russia (Altai) by Marusik et al (2004) instead of Kazakhstan (East Kazakhstan Area). The new record from the Karagemskyi Mt Range is the first locality record of this species in Russia.

\section{Discussion}

Synonymizing these two names reduced the number of species known in the genus to 27. Although the number of Acantholycosa species in the Altai-Sayan Mountain Region decreased from 20 to 19, this region still has the highest species diversity and endemism (59\%) in the entire range of the genus. The record of $A$. katunensis from the Russian Altai increased the number of Acantholycosa species found in Russia from 21 to 22. Judging from the high level of endemism in the Altai-Sayan Mountain Region, the limited distribution of species in that area, habitat preferences (stony screes) and the number of unexplored mountain ranges in the West and East Sayan Mountains (cf. Marusik et al. 2004: map 1) and the lack of material from adjacent Xinjiang (China) and Mongolia, many new species are expected.

\section{Acknowledgements}

We are grateful to R.V. Yakovlev (Barnaul, Russia), S.Yu. Sinev (Saint Petersburg, Russia) and A.V. Pershin (Biysk, Russia) for their help organizing the field trip to the Altai in which the material treated in this paper was collected. We also thank G.N. Azarkina (ISEA) for providing access to the comparative material from the ISEA. English of the earlier draft was kindly checked by Sarah Crews (CAS, USA). 


\section{References}

Fomichev AA, Marusik YM (2011) First description of the female of Acantholycosa logunovi (Araneae: Lycosidae). Zootaxa 2813: 65-68.

Kronestedt T, Marusik YM (2002) On Acantholycosa solituda (Levi \& Levi) and A. sterneri (Marusik) (Araneae: Lycosidae), a pair of geographically distant allied species. Acta Arachnologica, Tokyo 51: 63-71. doi: 10.2476/asjaa.51.63

Marusik YM, Azarkina GN, Koponen S (2004) A survey of east Palaearctic Lycosidae (Aranei). II. Genus Acantholycosa F. Dahl, 1908 and related new genera. Arthropoda Selecta 12: 101-148.

Marusik YM, Logunov DV (2011) New faunistic records of spiders from East Kazakhstan (Arachnida: Aranei). Arthropoda Selecta 20: 57-63.

Marusik YM, Omelko MM (2011) A survey of East Palaearctic Lycosidae (Araneae). 7. A new species of Acantholycosa Dahl, 1908 from the Russian Far East. ZooKeys 79: 1-10. doi: 10.3897/zookeys.79.945

Platnick NI (2004-2014) The world spider catalog, versions 5.0-15.0 American Museum of Natural History. http://www.wsc.nmbe.ch/archive/

World Spider Catalog (2015) World Spider Catalog. Natural History Museum Bern. http:// wsc.nmbe.ch, version 16.5. [accessed on October 29, 2015] 